\title{
Miłosz wobec Brzozowskiego. O Człowieku wśród skorpionów... i nie tylko
}

„Nie bój się ich ani nie lękaj ich słów, nawet gdyby wokół ciebie były osty i ciernie i gdybyś się znalazł wśród skorpionów" (Ez 2, 6) - kończąc w roku 1962 pracę nad Cztowiekiem wóród skorpionów. Studium o Stanistawie Brzozowskim i zaznaczając, że głównym jego celem było upomnienie się o „właściwą rangę krzywdzonego pisarza" słowa, którymi zwraca się Bóg do Ezechiasza. Teza Kazimierza Wyki z 1933 r., iż Brzozowski miał pecha do słowa „legenda”, była pozbawiona wymowy humorystycznej 30 lat później, gdy rozgrywał się dramat pośmiertny autora Idei... - dramat losów jego spuścizny, uwikłanej w dziedzinę biograficznych plotek, pomówień, zniekształceń i spekulacji. Eseistyka, publicystyka i twórczość krytycznoliteracka Brzozowskiego tworzyły całość znaną zazwyczaj fragmentarycznie, nieujętą jeszcze $\mathrm{w}$ żadną pełną monografię „dróg myśli” krytyka-filozofa ${ }^{2}$, nowe wydania jego pism stanowiły nieokreśloną w czasie niewiadomą, więc, jak pisze Miłosz, „ktoś musiał się zdobyć na apologię” (s. 167).

I C. Miłosz, Człowiek wśród skorpionów. Studium o Stanistawie Brzozowskim, Paryż 1962, s. 12. W dalszej części artykułu strony cytowanych z tej książki fragmentów będę podawała w nawiasach w tekście głównym.

${ }_{2} \mathrm{~W}$ zasadzie jedyną powojenną książką o autorze Idei była w tym czasie, znana Miłoszowi we fragmentach z lektury „Kultury i Społeczeństwa” (1961), monografia Andrzeja Stawara O Brzozowskim (Warszawa 1961), w której autor, według opinii Miłosza, nieobiektywnie „krytykuje Brzozowskiego ze swoich pozycji marksisty" (s. 101). W tym miejscu trzeba przypomnieć także przedwojenną monografię Brzozowskiego autorstwa Bogdana Suchodolskiego, Rozwój ideologii (Warszawa 1933), której Miłosz - jak sam przyznaje - nie znał (por. C. Miłosz, Człowiek wśród skorpionów..., s. 57) oraz niewielką książeczkę Zdziechowskiego Gloryfikacja pracy-myśli z pism i o pismach Stanistawa Brzozowskiego (Kraków 1921), do której Miłosz dotarł po ukończeniu swojej książki (por. C. Miłosz, Postscriptum, w: Człowiek wśród skorpionów..., s. 168). 
Nią właśnie jest książka o Brzozowskim, pisana bez ambicji do „stawiania kropek nad i, i bez pretensji do oceny trwałej”.

W efekcie w stanowiącym centralną część książki rozdziale o filozofii Brzozowskiego, spełniającym bardziej cele doraźne i popularyzatorskie niż analitycznogeneralizujące ( $z$ jednej strony bowiem oparte na ograniczonym materiale źródłowym, do którego miał dostęp w Paryżu i za Oceanem sam Miłosz, $\mathrm{z}$ drugiej - kierowane pierwotnie do francuskiego adresata, któremu Brzozowski był już zupełnie nieznany), aktualizowana jest poetyka tekstu: autor zamiast interpretować - znika, by ustąpić miejsca samemu filozofowi, pozwolić mu przemówić własnym głosem. W ten sposób merytorycznie zasadnicza partia monografii Brzozowskiego, przedstawiająca jego idee ontologiczne i światopoglądowe, przekształca się - jak przyznaje Miłosz - w „katalog filozoficznych motywów” (s. 114), stanowiących w zasadzie nowe dzieło Brzozowskiego, złożone $\mathrm{z}$ uporządkowanych według zagadnień fragmentów innych dzieł. Komentarz autora zostaje tu ograniczony do minimum i pojawia się głównie w ukrytym kryterium doboru i kompozycji materiału, a powściągliwość interpretacyjna znika dopiero wtedy, gdy konfrontuje on myśli Brzozowskiego z systemami filozoficznymi spoza jego macierzystej epoki (Jean-Paul Sartre, Borys Pasternak, Henri Lefebvre, George Lukacs, André Malraux, Simone Weil) po to, by wyeksponować oryginalność, doniosłość, a nawet proroczy charakter analiz autora Idei... („Sartre mówił w 1961 z katedry niemal to samo, co Brzozowski napisał ponad 50 lat temu w Ideach" - s. 170). W Historii literatury polskiej Miłosz powtórzy i wzmocni tezę sugerowaną w Człowieku wśród skorpionów...: niezrozumienie Brzozowskiego przez współczesnych spowodowane było nowatorstwem i pionierską wymowa jego tekstów, podjęciem tych tematów, które „wynurzyły się na powierzchnię w polskich i europejskich kręgach intelektualnych dopiero po drugiej wojnie światowej pod wpływem egzystencjalizmu i nurtu głoszącego «powrót do wczesnego Marksa»"3.

Całość ujęcia kompozycyjnego studium o Brzozowskim wyznacza triada: biografia - twórczość - recepcja ${ }^{4}$. Ukrytym założeniem Miłosza jest przekonanie, że dopiero analiza tych trzech komponentów prześwietli fenomen Brzozowskiego, będąc splotem współzależności: sens twórczości wyłania się bowiem na tle sensu znaczenia biografii, ta natomiast uwikłana jest $\mathrm{w}$ recepcję

3 C. Miłosz, Historia literatury polskiej, Kraków 1993, s. 431.

4 Por. P.J. Drozdowskie, Stanisław Brzozowski w świetle dwu analiz, „Przegląd Humanistyczny" 1987, nr 7/8, s. 29-30. 
samej twórczości, recepcja zaś jest nieczytelna bez uprzedniego zrozumienia pozostałych. W owej triadzie wyróżnione miejsce zajmuje tzw. sprawa Brzozowskiego, która zyskuje tym samym wyjątkową pozycję w książce Miłosza - autor poświęca jej obszerny rozdział, przywołując szczegółowe, wyczerpujące informacje i anegdoty dotyczące kontekstu i przebiegu wydarzeń towarzyszących rzekomej zdradzie. Rekonstrukcja sytuacji biograficznej Brzozowskiego przeprowadzana jest przez Miłosza z perspektywy analizy zjawisk i procesów socjologicznych, politycznych oraz historycznych, ujawniających rzeczywiste oblicze przyjmowanych wobec Brzozowskiego stanowisk „za” i „przeciw”. „Nie wierzyłem, że Brzozowski był płatnym agentem carskiej Ochrany - pisze po latach Miłosz - ale obława na niego wskazywała na stałe cechy polskiej wspólnoty wiecznie gnębionej i zagrożonej, wskutek czego skłonnej obarczyć epitetem «zdrajca» każdego, kto się wychylił"”.

Ostatecznie Miłosz rekonstruuje przełomowy i tragiczny moment biografii Brzozowskiego głównie przez pryzmat jego recepcji. Nie mniej niż odsłonięcie motywacji i kulis zachowań autora Ptomieni interesuje go identyfikacja kompleksu ukrytych założeń i stylów uzasadnień ataków na Brzozowskiego, formułowanych zarówno przez jemu współczesnych, jak i funkcjonujących w oddaleniu czasowym, a mimo to zadziwiających uporczywością trwania. Ta perspektywa czytania przeszłości zakłada po pierwsze, że przeszłość odsłania swe znaczenia w kontekście późniejszych oddziaływań oraz dzięki serii późniejszych aktualizacji i, po drugie, że - jak u Wilhelma Diltheya - współczesność jest nam dana nie tylko wprost, ale przez odnajdywanie tożsamości zaszyfrowanej w historii.

I „sprawę”, i twórczość Brzozowskiego czytać więc postanawia Miłosz, zaczynając od późniejszych oddziaływań, uwikłania znaczeń wydarzeń i tekstów w konteksty ich interpretacji, hermeneutycznego aktualizowania sensów wciąż na nowo. Ta metodologiczna perspektywa tematyzowana jest w książce wprost: „Brzozowski czytany dzisiaj - pisze Miłosz - nie jest tym samym co dla współczesnych, bo kładziemy jego książki na stole razem z innymi, które o wiele później nadawały kształt tym samym wątkom" (s. 113). Konsekwencją takiego sposobu widzenia historii i myśli jest projekcja dzieła filozofa na ekran dwudziestowiecznej współczesności, ale konsekwencją jest także, a może przede wszystkim, przekonanie odsłaniające najgłębszą chyba

5 C. Miłosz, Przypispo latach, w: Człowiek wśródskorpionów, Kraków 2000, s. 7. 
intencję książki, którą jest mówienie o nas samych cudzymi myślami, mówienie o współczesności przez odnajdywanie klucza do jej zrozumienia w przeszłości, w historycznie uzasadnionych mechanizmach funkcjonowania kultur i narodów.

Tematyzowaną przez Miłosza motywacją zajęcia się Brzozowskim jest bowiem potrzeba przezwyciężenia dystansu, ekspiacja wobec pisarza, o którym w 1943 r. napisał, że „jest odrażający”: „Dlaczego w roku 1943 w szkicu o Stanisławie Ignacym Witkiewiczu, przyznając, że są dwie osobowości w polskiej nowszej literaturze, do których trzeba ciagle powracać: Brzozowski i Witkiewicz, napisałem, że Brzozowski jest odrażający? - pyta Miłosz w książce - [...] Nieuczciwość zwykle pochodzi z podszeptów ambicji. Podziemne pisemka prawicowe doprowadziły mnie do furii, a w nich bez ustanku: Brzozowski, Brzozowski. Spreparowany przesłonił mi prawdziwego" (s. 61). Ambiwalencja Miłosza wobec autora Idei... spowodowana była w latach 40 . zawłaszczeniem Brzozowskiego przez prawicę, do czego krytyk dawał zachętę, przyznając się do katolicyzmu Jana Henryka Newmana, eksponując rolę narodu w kształtowaniu się świadomości historycznej i etycznej społeczności oraz jednostek, a także wypowiadając się pochlebnie o filozofii polskich romantyków. Sam Miłosz bywał w tym czasie atakowany przez zwolenników Brzozowskiego. Gdy w 1942 r. dyskutował z Tadeuszem Gajcym, Wacławem Bojarskim, Andrzejem Trzebińskim, ten ostatni w późniejszej polemice na łamach „Sztuki i Narodu” zarzucając mu niemożność sprostania wyzwaniom dnia dzisiejszego, „drażniącą ślepotę filozoficzną w niezrozumieniu irracjonalizmu”, apelując o świadomość, iż „[s]kończyła się epoka słów w literaturze musi się w niej zaczać epoka czynu" - wspierał się w swych wystapieniach przeciwko Miłoszowi właśnie autorytetem Brzozowskiego ${ }^{6}$. Ta "prawicowa heca brzydziła mnie - napisze Miłosz po latach - w moim zajęciu się Brzozowskim po wojnie wolno dopatrzeć się zamiaru go odkażenia i dojścia z nim do zgody"7.

Nie lekceważąc tej motywacji książki, wprost wyartykułowanej przez autora, można dojść do wniosku, że rzeczywistą, podskórną, głęboką i najbardziej znaczącą jej genezą, wypływającą z założenia już sygnalizowanej metody jej autora (założenia, które tematyzuje zresztą Miłosz nie tylko w książce o Brzozowskim, ale choćby recenzując listownie Osobowość $i$ bistorię Walickiego, gdzie, akceptując charakter naukowego pisarstwa, zwierza się: ,,ja

\footnotetext{
${ }^{6}$ Por. A. Franaszek, Mitosz. Biografia, Kraków 2011, s. 340.

7 C. Miłosz, Przypispo latach, s. 6.
} 
jako eseista, nie historyk, wolałbym silniejsze powiązanie z tym, co nas dzisiaj niepokoi" $\left.{ }^{8}\right)$, jest próba wypowiedzenia siebie, własnej sytuacji i jak najbardziej aktualnych diagnoz współczesnej Miłoszowi teraźniejszości. W istocie i w konsekwencji zatem „rzecz o Brzozowskim jest książką o samym Miłoszu”, a „sprawa Brzozowskiego" jest poniekąd także jego sprawą - jak pisano tuż po opublikowaniu książki w Polsce ${ }^{9}$. „Rzeczywiście - przyzna Miłosz po przeszło 50 latach - nadając ten tytuł utożsamiłem się z florenckim samotnikiem miotającym się wśród jadowitych podejrzeń”, „pamięć o swoich doświadczeniach zmieniła dzieło szkolarza w dzieło współczucia”" Dlatego „szkic niniejszy nie jest chłodną rozprawą badacza" (s. 34), i dlatego - znów zwierzenie kierowane listownie do Walickiego - „nie mam żadnych ambicji pionierskich badań, kawałek wiosła jest mi potrzebny jako człowiekowi" ${ }^{11}$.

Tragiczny wybór: „być Polakiem czy być człowiekiem” wyrażał bowiem wspólny merytoryczny dylemat Brzozowskiego i Miłosza, a praktyczna decyzja o życiu na obczyźnie stanowiła ich wspólną własność. Książka o Brzozowskim okazuje się $\mathrm{w}$ pewnym sensie zakamuflowanym zwierzeniem samego Miłosza, czego najgłębszym świadectwem jest zbieżność problemów, tematów, wątków, jakie wydobywa z pism Brzozowskiego Miłosz, z tymi, które wyraźnie pojawiają się (czy też wkrótce pojawią się) i w jego twórczości. Obecny w Człowieku wśród skorpionów... silny, nie zawsze artykułowany wprost wątek osobisty, odsłaniający najwartościowszy wymiar książki, narzuca zatem pytanie o inspiracje - drogi dialogu Miłosza z Brzozowskim - i zachęca do zbadania nieusystematyzowanych wyraźnie punktów wspólnych obu twórców. Zachęca do tego zresztą sam Miłosz wkomponowanym w tekst wyznaniem, w którym mówi o dhugu zaciągniętym przez całe pokolenie u autora Kultury $i z \dot{z} y$ cia, w treści i radykalizmie jego postawy. Pisze:

Po bardzo długiej przerwie od roku 1930-1932, kiedy jako zielony młodzieniaszek przeczytałem kilka tomów Brzozowskiego, do roku 1959, kiedy postanowiłem zabrać się do niego gruntownie - powstało we mnie półpodejrzenie, półpewność, że to on właśnie był regulatorem. I bodaj nie jestem w tym zaciąganiu długu wyjątkiem.

${ }^{8}$ List Miłosza do A. Walickiego z 19 listopada 1960 r., w: A. Walicki, Spotkania z Mitoszem, Londyn 1985, s. 164.

9 Por. D. Ulicka, Sprawa nie tylko Brzozowskiego, „Miesięcznik Literacki” 1982 , nr 12.

то C. Miłosz, Przypispo latach, s. 9.

II A. Walicki, op.cit., s. 163. 
Moje pokolenie wystawione na wiatry historyczne, czy wręcz wystawione do wiatru, usiłowało dość niedołężnie umieścić jednostkę w społeczeństwie, pogodzić sztukę z zaangażowaniem. Filozofia uniwersytecka przynosiła mało pożytku. [...] Natomiast aktualności społecznych obowiązków literatury tykali właściwie tylko marksiści, ale beznadziejnie wulgaryzując, ani talentem, ani wiedzą nie mogli równać się z Brzozowskim. Zestawieni z nim, słabli. (s. 59-60)

Skupiająca się na pokoleniowym wątku genezy Człowieka wśród skorpionów... Marta Wyka napisze, że ślad prowadzi ku wspólnym przeżyciom pokolenia Miłosza. Brzozowski nadawał sens jego ideowym rozterkom. Istnieje bowiem znamienite pokrewieństwo pomiędzy umysłową inicjacją samego Brzozowskiego a poszukiwaniami Miłosza i jego rówieśników ${ }^{12}$. Będąc zatem dla pokolenia 1910 „partnerem niechcianym” (Ludwik Fryde) lub „partnerem koniecznym” (Kazimierz Wyka), Brzozowski okazuje się wyjątkowo przydatny: „Wchodzi w tę atmosferę niepokoju, pesymizmu, ale również zachłanności intelektualnej, ale również głodu wiedzy filozoficznej i politycznej, wyjątkowo harmonijnie. Broni go i zaleca własne zawikłanie, własny niepokój, własne nieustanne poszukiwanie uzasadnień ogólnych dla losu szczegółowego" ${ }^{13}$.

Jaką postać, formę, temperaturę pokoleniowe inspiracje Brzozowskim przybierają w twórczości Miłosza?

Pierwsza odsłona wpływów Brzozowskiego wiąże się z zachętą, jaką młody Miłosz w latach 30. czerpał z pism krytyka do - jak sam pisze - „lewicowego fanatyzmu” ${ }^{14}$ :

[...] jedynym kryterium osądzania dzieła sztuki jest jego rola społeczna - deklarował stanowczo, w stylu Brzozowskiego, pisząc w 1931 r. list do Jarosława Iwaszkiewicza - Czy wiersz jest dobry, poznajemy rozpatrzywszy wpływy, jakie wywrze na psychikę społeczną. Dość już nastawienia liberalnego, równouprawnienia wszystkiego, trzeba rehabilitować fanatyzm ${ }^{15}$.

Kulminację nastrojów rewolucyjnych osiąga Miłosz w pogardliwym w stylistyce i tonie Bulionie z grwoździ („Żagary” 1931), będącym gwałtownym atakiem na brak głębszych intelek-

I2 Por. M. Wyka, Miłoszi Brzozowski, w: Poznawanie Mitosza. Studia iszkice o twórczości poety, red. J. Kwiatkowski, Kraków 1985, s. 510.

I3 M. Wyka, op.cit., s. 551.

I4 C. Miłosz, Przypis po latach, s. 6.

15 List Miłosza do Iwaszkiewicza z 1 listopada 1931 r., Wilno, w: C. Miłosz, J. Iwaszkiewicz, Portret podwójny, Warszawa 2011, s. 51-52. 
tualnych motywacji polskich twórców. Ich „stosunek do zagadnień społecznych i politycznych jest niezorganizowany, czysto uczuciowy” - pisał Miłosz z pretensją - podczas gdy „[a]rtysta kieruje hodowlą ludzi [...], sam układ i dobór słów, użycie pewnych metafor, takie lub inne operowanie rytmem lub rymem wszystko to wywiera ogromny wpływ na umysłowość odbiorcy i ryje się głęboko wytyczając nawet przekonania polityczne”.

Dzieło sztuki winno być, według Miłosza, oceniane z perspektywy motywacji politycznych, sztuka jest utylitarnym „narzędziem $w$ walce społeczeństw o wygodniejsze formy bytu [...]. Producent dóbr artystycznych powinien mieć jasny i wyraźny cel. Tym celem powinno być urobienie takiego typu człowieka, jaki ze względów społecznych jest w najbliższym czasie potrzebny" ${ }^{16}$.

„Bulion z grwoździ jest dziko totalitarny, ale to w małym stopniu wywodzi się $\mathrm{z}$ ducha rosyjskiego, to Brzozowski jest za to odpowiedzialny, trochę go posunąłem" - przyznaje Miłosz po latach w rozmowie z Aleksandrem Fiutem. Brzozowski, odnotujmy, funkcjonuje w tym tekście jako ukryte, niestematyzowane, bo nieprzywołane z nazwiska, źródło radykalizmu; dług Miłosza polega na znalezieniu w pewnych punktach ideologii autora Kultury $i$ życia argumentów dla rehabilitacji wspominanego w liście do Iwaszkiewicza, a pożądanego przez niego naówczas, fanatyzmu.

Powtarza zatem Miłosz za Brzozowskim atak na postawę bierno-kontemplacyjną, będąc - jak on - rzecznikiem aktywności artysty i jej społeczno-politycznego znaczenia. Powtarza ten atak $\mathrm{w}$ wersji patetycznej i zwulgaryzowanej, tendencyjnie zideologizowanej, takiej, jaką zaprezentował młodopolski krytyk w serii artykułów z 1905 r., żądając bezpośredniego udziału sztuki w życiu społecznym, formułując dyrektywę literatury politycznie zaangażowanej i dydaktycznej, oskarżając wreszcie sztukę niewłączającą się na poziomie prezentowanych tematów i formułowanych przesłań o błahość, a jej twórców - o tchórzostwo i bezsilność.

Ta dyrektywa wyznaczająca intencje i cele literatury łączona jest przez Miłosza z po raz pierwszy tak wyraźnie tematyzowaną w polskiej krytyce literackiej przez Brzozowskiego, a w latach 20. i 30. XX w. określającą już niemal całą awangardę, świadomością formy jako struktury znaczącej, także w aspekcie społecznym i utylitarnym; tak jak Brzozowski - Miłosz opowiada się w szkicu za traktowaniem technicznych i kompozycyjnych

I6 C. Miłosz, Bulion z grwoździ, „Żagary”, grudzień 1931, cytaty za: C. Miłosz, Przygody młodego umystu, Kraków 2003, s. 31. 
(rymy) aspektów dzieła jako zagadnień w ostatecznej instancji politycznych.

Mimo skrajności reprezentowanej $\mathrm{w}$ tym tekście postawy Miłosz zdradza w nim stałe $-\mathrm{z}$ ducha Brzozowskiego właśnie motywy swego późniejszego pisarstwa: atak na antyintelektualizm, nieufność wobec spontanicznej emocjonalności i przekonanie o odpowiedzialności społeczno-moralnej artysty: „zamiast emocjonalności - dyktatura intelektu, zamiast biologii - socjologia” - przekonuje. „Marzę o szkole literackiej - zwierza się Iwaszkiewiczowi - która by postawiła jako naczelną zasadę: poezja organizacją intelektu i zakazałaby w definitywny sposób zwalczać wszelkie bezpośrednie uniesienia” ${ }^{17}$. „Kiedyż nareszcie sztuka będzie budowlą opartą na ziemi? Dotychczas jest kolorowym balonikiem bujającym wysoko nad otwartymi z podziwem gębami tłumu" 18 .

Ten Miłoszowy, artykułowany później przez niego na różne sposoby, atak na antyintelektualizm powtarza $\mathrm{w}$ pewnym sensie motywy sprzeciwu Brzozowskiego wobec wyabsolutyzowanej sztuki Miriama czy światopoglądowych założeń estetyki symbolizmu. Brzozowski portretowany w Człowieku wśród skorpionów... jest filozofem sojusznikiem w kampanii antyintelektualnej samego Miłosza. I choć młodopolski adwersarz Brzozowskiego zarzuci mu, iż w jego pismach „myśl [...] ukorzyła się [...], aby wleźć w czyn" ${ }^{19}$ (Karol Irzykowski), a późniejszy interpretator jego postawy (Tomasz Burek) będzie przekonywać, nie bez słuszności przecież, że Brzozowski, „stając zawsze po stronie aktywizmu filozoficznego, będącego wyróżnikiem nowych prądów filozoficznych - nietzcheanizmu, bergsonizmu, pragmatyzmu - przeciwstawia się intelektualizmowi”" ${ }^{20}$, to sam Miłosz wyeksponuje te wątki, motywy i momenty fenomenu Brzozowskiego, które stawiają go po stronie myśli usytuowanej biegunowo wobec emocji. Argumenty eksponować będzie Miłosz trzy.

Po pierwsze, metoda Brzozowskiego, która zrodzona jest $\mathrm{z}$ intelektualnej pazerności, rzec by można - żarłoczności, metoda mająca swe korzenie w przekonaniach antropologicznych krytyka, zgodnie z którymi, jak pisze Miłosz, „główną przeszkodą $\mathrm{w}$ dążeniu do pełnego człowieczeństwa jest niewiara

${ }^{17}$ List Miłosza do Iwaszkiewicza z 20 października 1931 r., Wilno, w: C. Miłosz, J. Iwaszkiewicz, op.cit., s. 50.

I8 C. Miłosz, Bulion z grwoździ, s. 31.

I9 K. Irzykowski, Czyn i stowo, Kraków 1980, s. 421.

${ }^{20}$ T. Burek, Cztery dyskusje Karola Irzykowskiego, w: Problemy literatury polskiej lat 1890-1939, seria I, red. H. Kirchner, Z. Żabicki, Wrocław 1972, s. 149. 
w intelekt” (s. 14). „Spokój to pułapka ześlizgiwania się w bezwład" (s. 15).

Po drugie, sprzeciwy krytycznoliterackie Brzozowskiego, z których Miłosz wskaże na protest autora Legendy Młodej Polski... wobec biernej wzruszeniowości Stefana Żeromskiego, przeciwstawionej zdecydowanie wyżej ocenianej woli Fiodora Dostojewskiego. Notabene w wątku krytycznoliterackim $\mathrm{Mi}-$ łosz wierny postawie antywzruszeniowości zgani Brzozowskiego za impresjonistyczną jego zdaniem metodę uprawiania krytyki (zob. s. 41).

Po trzecie wreszcie, co najistotniejsze, bo żywotnie interesujące samego Miłosza ze względu na aktualność oceny sformułowanej przed laty: krytyczna ocena polskiej inteligencji, która „myśl zastępuje towarzyskością” (s. 16). „Z jakim pańskim spokojem, z jaką dezynwolturą sądów tu klepano po ramieniu idee i ludzi” - pisał Brzozowski w Płomieniach będących, jak pisze Miłosz w Historii literatury polskiej, „manifestacją intelektualnych możliwości autora" ${ }^{21}$.

Potrzebę autentyzmu, traktowania problemów i myśli na serio, niechęć, a nawet moralne potępienie wobec „zabawowego” stosunku do życia intelektualnego, wobec traktowania go jako towarzyskiej gry dostrzega Miłosz u Brzozowskiego, interpretując te zjawiska w aktualizowanej na bieżąco w dialogach z Tadeuszem Krońskim i Andrzejem Walickim kategorii alienacji, rozumianej jako „zafałszowanie świadomości, oddanie jej na łup irracjonalizmu” ${ }^{22}$; „polska inteligencja nie znosi tylko jednego: przejęcia się zagadnieniami fundamentalnymi” (s. 124) - podsumowuje Miłosz - „dramat Brzozowskiego może być więc mierzony późniejszymi sukcesami Boya” (s. 159).

Ale „emancypacja umysłowa równała się dla Brzozowskiego protestowi przeciwko swemu rodzinnemu środowisku, tj. przeciwko Polsce rozczulającego obyczaju katolickiego kościółka, kultu narodowego męczeństwa i programowego antyintelektualizmu. Być człowiekiem czy być Polakiem, w którym człowiek przez samą przynależność do narodowej grupy i poddanie się jej nakazom jest umniejszony?” (s. 98).

Protest przeciwko antyintelektualizmowi łączy się - zarówno u Brzozowskiego, jak i u Miłosza - z protestem przeciwko polskości, rozumianej jako zbiór romantycznych symboli i gestów (tu podobieństwo z Brzozowskim zapowiada późniejszą

${ }^{21}$ C. Miłosz, Historia literatury polskiej, s. 431.

${ }_{22}$ M. Janion, Kroński - Miłosz. Epizod z dziejów myśli i poezji, w: Do Europy - tak, ale z naszymi umartymi, Warszawa 2000, s. 230. 
zbieżność w tej kwestii Miłosza z Gombrowiczem $\left.{ }^{23}\right)$. Jak Płomienie zdradzają antypolską obsesję Brzozowskiego (według Miłosza trzeba je interpretować jako próbę pojedynku „z obsesją wyzwolenia się od Polski” - s. 18), jak jego listy ${ }^{24}$ i Legenda Młodej Polski... dowodzą szyderczego stosunku ich autora do bogoojczyźnianego i epigońsko-romantycznego tradycjonalizmu polskiego, jako zapis przeprowadzanej przez niego bezkompromisowo krytyki polskiej kultury szlacheckiej opartej na ludowym katolicyzmie ${ }^{25}$ - tak cała twórczość Miłosza poświadcza, sam przyznaje, jego „alergię na polskość” ${ }^{26}$. W Zniewolonym umyśle, komentując swoje „zapasy z polskością” ${ }^{27}$, Miłosz napisze deklaracyjnie: „O moim konflikcie z polską obyczajowością [...] świadczą wszystkie moje książki” ${ }^{28}$. W Rodzinnej Europie, w eseju Podróż na Zachód, wyzna:

23 O relacji Miłosz - Gombrowicz patrz: A. Mencwel, Dialog nie dopowiedziany: Gombrowicz i Miłosz, w: Poznawanie Miłosza 2. Część druga 1980-1998, red. A. Fiut, Kraków 2001, s. 125-155. Uwidaczniająca się w ironicznym stosunku do tradycjonalizmu polskiego zbieżność postawy Miłosza z myśleniem zarówno Brzozowskiego, jak i Gombrowicza pośrednio wskazuje na podobieństwo autora Legendy Młodej Polski i twórcy Ferdydurke. Podobieństwo to (Brzozowski - Gombrowicz) interpretuje Marta Piwińska (zob. M. Piwińska, Legenda romantyczna i jej szydercy, Warszawa 1973, s. 147-148). Gombrowicz jednak po lekturze Miłoszowego Człowieka wśród skorpionów... eksponuje różnicę swego światopoglądu z filozofią Brzozowskiego: „Widzę nawet, czytając pracę Miłosza, że jestem w sprzeczności z tym filozofem [Brzozowskim] tak ostrej i zasadniczej, jak może dziś żaden z oświeconych Polaków" (W. Gombrowicz, Dzienniki (1961-1966), Paryż 1971, s. 51). O „symetryczności przeciwieństwa” Brzozowski - Gombrowicz pisze Andrzej Walicki (zob. A. Walicki, Stanistaw Brzozoweski. Drogi myśli, Warszawa 1977, s. 465-466).

${ }^{24}$ Apogeum goryczy wobec Polski wyraża Brzozowski w listach stanowiących reakcję na oskarżenie go o współpracę z ochraną: „Z Polską oczywiście moje rachunki zamknięte. [...] W Polsce nie chcę leżeć nawet po śmierci. Pewnych rzeczy się nie przebacza” (S. Brzozowski, Listy, t. 1, Kraków 1970, s. 515, 606).

${ }_{25}$ Religijność „Polski zdziecinniałej” oddają słowa z Legendy.... „Polak wie, że mszę się odprawia, że żona i służba chodzą do spowiedzi, że jest święcone i że przed śmiercią trzeba będzie o tym wszystkim pomyśleć" (s. 47). Adekwatnym portretem tak pojętej mentalności były dla Brzozowskiego powieści Sienkiewicza ( tu Legenda... jest kontynuacją kampanii antysienkiewiczowskiej krytyka) - Brzozowski eksponuje wstręt, jaki wzbudza w nim „polska beztroska połaniecczyzna, która ukuła sobie religię po prostu z niechęci myślenia, zastanawiania się nad czymkolwiek, która rezygnuje ze wszystkiego, byle się jej dobrze spało" (s. 48).

${ }^{26}$ W Prywatnych obowiazkach Miłosz - postawiwszy pytanie: „Czy można być wiernym literaturze polskiej, ją lubić, jej służyć, a zarazem okazywać narodową jakby obojętność?” - przyznaje otwarcie: „na polskość jestem alergiczny" (s. 82).

27 Określenie A. Fiuta - zob. A. Fiut, Moment wieczny. Poezja Czestawa Miłosza, Libella-Paris 1987.

${ }^{28}$ C. Miłosz, Zniewolony umyst, s. 129. 
Polska nam ciążyła. Mieszkać w niej to było jak chodzić po tafli lodu - a pod nią wykrzywiały się miliony zdeformowanych koszmarnych twarzy. Brak jednolitego wzorca uniemożliwiał odbiór człowieka „jako takiego” - na pierwszy plan wysuwał się jego status: inteligent, chłop, Żyd. I nie polityka okresu naszego dzieciństwa ponosiła za to odpowiedzialność, ale stulecia ${ }^{29}$.

O ile jednak Miłosz miał alergię na słowo „naród” (w książce o Brzozowskim pisze na przykład, że „naród” i „,narodowy” to słowa, które „pomiędzy r. 1918 i 1939 tak zostały zmonopolizowane przez endecję, że nie ośmielił się ich wymawiać żaden lewicowiec ani liberał, bo «narodowy» znaczyło prawicowy" s. 48$)^{30}$ - o tyle dla Brzozowskiego kategoria narodu określała dobitnie konieczną i potrzebną formę ludzkiego uspołecznienia podporządkowaną wartościom.

Przeżywany zatem zarówno przez Brzozowskiego, jak i przez Miłosza protest przeciwko swemu środowisku ${ }^{31}$, wywołujący atak na apatię intelektualną jako na jego rękojmię i gwarancję, owocował, podkreśla Marta Wyka ${ }^{32}$, podobnymi ścieżkami odnajdywania rozwiązań. Koncepcja Marksa, ateizm i Rosja wskazywały perspektywę wyjścia poza polski zaścianek. Rosja znaczyła dla Brzozowskiego tyle, co aprobata i podziw dla inteligencji rosyjskiej, dla jej chłonności na nowe w filozofii i literaturze; kultura rosyjska działała wyzwalająco i wzmacniała moralnie. Podobnie dla Miłosza - jak wspomina w Znierwolonym umyśle lata swojej młodości:

Coraz częściej w naszych rozmowach zaczęło pojawiać się słowo Rosja [...]. Tamten świat znany z książki pojawiał się jako świat postępu, kiedy porównywaliśmy go z naszymi stosunkami, które mogliśmy oglądać z bliska [...]. Ruch nacjonalistyczny - oparty na drobnomieszczaństwie i zubożałej inteligencji, popierał rząd do coraz ostrzejszych dyskryminacji [...]. Czyż można się dziwić,

29 C. Miłosz, Rodzinna Europa, Warszawa 1990, s. 174.

30 Polemikę z Miłoszem na ten temat prowadził Andrzej Walicki (zob. A. Walicki, Spotkania z Miłoszem, s. 146-151); o stosunku Miłosza do pojęcia narodu mowa w książce Aleksandra Fiuta (zob. A. Fiut, Wobec narodu, w: Moment wieczny. Poezja Czesława Miłosza, Paryż 1987, s. 128-138).

$3^{\text {I }}$ „[...] wszyscy byliśmy zrewoltowani przeciwko swemu środowisku wywodziliśmy się z inteligencji, która w tej części Europy była synonimem zubożałej szlachty albo drobnomieszczaństwa $[.$.$] . [...] status społeczny nas wszyst-$ kich był nieokreślony, myślą przebywaliśmy w wieku XX, ale tradycje naszych rodzin cofały nas wstecz”. C. Miłosz, Zniewolony umyst, s. 78.

$3^{2}$ M. Wyka, op.cit., s. 552. 
że patrzyliśmy na Rosję jako na kraj, gdzie znaleziono rozwiązanie wszystkich dręczących nas problemów?33

Fascynacja Rosją, będąca w dużym stopniu właśnie fascynacją marksizmem, zachęca zatem Miłosza do poświęcenia rozbudowanych partii książki analizie oraz ocenie filozofii Marksa sformułowanej przez Brzozowskiego. Interpretując ten wątek, Miłosz ceni autora Legendy Młodej Polski... za, jak dopowie już w Historii literatury polskiej, intuicję potrzebną do rekonstrukcji tez wczesnej myśli Marksa mimo: po pierwsze - niewydanych jeszcze wówczas tekstów filozofa z tego okresu (Rekopisy ekonomiczno-filozoficzne, 1933), po drugie - przekształceń wczesnych idei Marksa dokonanych przez niego samego w pismach późniejszych, po trzecie - zaciemnienia intencji filozofii Marksa przez wydobycie wyłącznie deterministycznych wątków materializmu dziejowego w stronniczych interpretacjach Engelsa. Stąd, jak diagnozował Brzozowski w Ideach..., „, być marksistą jest to dziś najlepsza może droga prowadząca do ślepoty i nieczułości bezwzględnej na wszystkie zagadnienia marksowskie" (s. 39).

Brzozowskiego lektura Marksa zakorzeniona jest w dialektycznym stosunku do romantyzmu i postawie dystansu wobec „naukowego światopoglądu”. Według autora Legendy Młodej Polski... scjentystyczna orientacja poznawcza i światopoglądowa drugiej połowy XIX w. opiera się na postromantycznym dualizmie duszy i świata, stanowiących oddzielne porządki ontologiczne i aksjologiczne. „Świat Darwina jest tylko jedną z metamorfoz świata Rousseau” (s. 38).

Tymczasem Brzozowski - pisze z aprobatą Miłosz - nie robił nic innego, jak prowadził dalej swoją operację odrywania się od darwinizmu i jego pochodnych. Materializm historyczny w jego ujęciu nie miał i nie mógł mieć nic wspólnego z całym repertuarem teorii, do jakich dały asumpt nauki przyrodnicze, był ich przeciwieństwem i rehabilitował jednostkę $\mathrm{w}$ jej działalności, w jej praxis. [...] Jeśli marksistom obce było wyzwalające znaczenie pism Marksa, bo naśladując Engelsa wydobywali z nich „koniecznościowe”, deterministyczne koncepcje, sami ponosili winę. (s. 39)

33 C. Miłosz Zniewolony umyst, s. 82. Z czasem Miłosz przyznaje się do wzrastającego w nim krytycyzmu wobec Rosji, w Rodzinnej Europie o literaturze rosyjskiej pisze: „Głębia literatury rosyjskiej była dla mnie zawsze podejrzana. Co z głębi, jeżeli kupuje się ją za zbyt dużą cenę? Czy z dwojga złego nie wolelibyśmy raczej «płytkości», byle z nią razem mieć porządnie zbudowane domy, ludzi sytych i zapobiegliwych? I co z potęgi, jeżeli zawsze jest potęgą centralnej władzy, a tymczasem w zaniedbanym prowincjonalnym miasteczku niezmiennie powtarza się Rezuizor Gogola?” (s. 151-152). 
Oczywiście interpretacja obecności marksizmu w myśli Brzozowskiego jest funkcjonującą w książce podskórnie próbą rozpoznania i artykułowania przez Miłosza własnej tożsamości historiozoficznej, diagnozowaniem powodów i motywacji własnej, jak napisze później, „muzykalności na marksizm”. Rekonstruując swój stosunek do marksizmu w latach 30., w Rodzinnej Europie Miłosz pisał, że nie deklarował się wówczas jako marksista, bo nie czytał Kapitału, że bardziej niż rozumem kierował się „węchem, który ostrzegał przed izmem”, że nie zapuszczał się w zawiłości filozofii „czemuś dla niego podejrzanej”, że do klasycznych dzieł Feuerbacha, Engelsa i Lenina podchodził „po literacku”. Z drugiej strony przyznaje, iż „doświadczenie marksistowskie” - „ostatecznie bardzo złożone” - było mu „jak najbardziej potrzebne" ${ }^{34}$.

W rozmowie z Renatą Gorczyńską, próbując niejako podsumować ten wątek i oddając marksizmowi pewne zasługi, jednoznacznie go zdezawuuje: „uważam marksizm za filozofię fałszywą i szkodliwą. [...] Natomiast nie neguję, że dzięki niemu nastąpiło uświadomienie sobie historyczności” ${ }^{35}$.

Stosunek Miłosza do marksizmu rozpatrywany na tle prowadzonych przez niego na przełomie lat 50. i 60. analiz tekstów Brzozowskiego pozwala odnotować, że wspólne są Brzozowskiemu i Miłoszowi dwa sprzeciwy związane z tym problemem. Po pierwsze - sprzeciw wobec wykładni „marksizmu krzepnącego w kościół”, czy to przez „obowiązujące” politycznie i okresowo jego wykładnie, czy też w obrębie dyrektyw niewychodzenia przez jego „wyznawców” poza materialistyczną wizję świata, opór wobec łączenia go z myślą metafizyczną i religijną (nieortodoksyjną współobecność marksistowskich inspiracji z refleksją religijną odnotować trzeba w tym miejscu w twórczości zarówno Brzozowskiego, jak i Miłosza). Po drugie - łączy Miłosza z Brzozowskim sprzeciw wobec interpretacji marksizmu przez Engelsa, podnoszącego skrajnie deterministyczny, odpodmiotowiony wymiar procesów historycznych:

$Z$ biegiem czasu zostanie uznaną niezaprzeczalna prawda, że Marks był przede wszystkim potężnym intuicyjnym umysłem filozoficznym: ale tego się nie zrozumie, póki będzie krążyć bajeczka o filozofie Engelsie, który był pierwszorzędnym publicystą, ale absolutnie nie wchodzi w rachubę jako filozof.

34 C. Miłosz, Rodzinna Europa, s. 120-121.

35 E. Czarnecka [R. Gorczyńska], Podróziny świata. Rozmowy z Czestawem Miłoszem. Komentarze, New York 1983, s. 86. 
Historyzm dogmatyczny - cytuje Miłosz z przekonaniem Brzozowskiego - równie dobrze jak dogmatyczny naturalizm jest zamaskowaną formą teoretycznego i etycznego nihilizmu. (s. 48)

Czytany w dużej mierze „przez” Brzozowskiego Marks funkcjonuje zatem dla Miłosza w latach 60. jako symbol pożądanego uwrażliwienia na myślenie historyczne, jako dyrektywa sytuowania człowieka w historycznym kontekście, ponieważ, jak napisze autor Rodzinnej Europy, „[c]złowieka można dosięgnąć tylko z ukosa, poprzez wszystko co jest jego przedłużeniem i ciągłą maskaradą, czyli w jego momencie historycznym" ${ }^{36}$. Marks z uporem przeciwstawiany Engelsowi wspiera też, co najważniejsze, eksponowaną przez Miłosza w filozofii autora Idei..., a bliską jemu samemu, perspektywę antropologiczną opartą na przeciwstawieniu ludzkiego pozaludzkiemu, a ludzkości (tj. historyczności właśnie) - przyrodzie.

Owo marksowskie, zapośredniczone przez lekturę pism Brzozowskiego, uwrażliwienie na historyzm zdradza zapowiedź już drugiego (po temacie zagrożenia formą polskości) wątku łączącego płaszczyznę czytania przez Miłosza myśli autora Kultury $i$ życia z podejmowanym przez niego dialogiem $\mathrm{z}$ Witoldem Gombrowiczem. Przypomnijmy: gdy Gombrowicz apeluje po lekturze Zniewolonego umystu i Zdobycia władzy o wyzwolenie się Miłosza spod wpływu dialektyki i Historii, ten, podejmując ważny dla siebie temat, formułuje w publikowanym w „Kulturze” tekście Gombrowiczowi (1953) pogłębioną refleksję o antynomii tego, co uniwersalne i jednostkowe, ogólne i szczegółowe, historyczne i ponadczasowe: „Żeby być historycznym trzeba być ponadhistorycznym. Ale to zdanie odwrócone też jest prawdziwe. Nie zdobędzie perspektywy wieków, kto nie tkwi w swojej epoce" ${ }^{37}$. W lekturze Brzozowskiego Miłosz eksponuje zatem ponownie to, co stanowi jeden z głównych motywów jego twórczości i wyznacza płaszczyznę innych ideowych sporów.

Historyzm funkcjonuje zatem w myśli Brzozowskiego w ostatecznej i najbardziej interesującej Miłosza postaci jako sposób sytuowania się ludzkości w opozycji do Natury, do przyrody, będącej rzeczywistością wobec człowieka niezależną i uprzednią. Przeciwstawiając się wszelkim „filozofiom bytowym”, Brzozowski widzi świat jako przestrzeń działalności człowieka, jako ustanawianą w czynie (pracy) i powołującą wartości relację człowieka w stosunku do rzeczywistości. „[J]edyną rzeczywistością jest konkretna poszczególna wartość, samoustanawiający

$3^{6}$ C. Miłosz, Rodzinna Europa, s. 158.

37 C. Miłosz, Gombrowiczowi, „Kultura” 1953, nr 10, przedruk w: C. Miłosz, Kentynenty, Kraków 1999, s. 274. 
się czyn, wyrażający się w działaniu, sądzie, odczuciu” (s. 77); „nie w poznaniu bytu lecz w stworzeniu człowieka leży podstawowe zadanie ludzkości” (s. 76); „świat nie jest żadną zamkniętą dokonaną całością, lecz sumą wielu procesów, z których każdy dąży do zorganizowania całości bytu" (s. 68) - mnoży Miłosz cytaty z pism Brzozowskiego, wyprowadzając główny wniosek: „stąd zamiast przeciwstawienia podmiot - przedmiot występuje u Brzozowskiego inne ludzkie - pozaludkie" (s. 67).

Tak przeczytany Brzozowski jest dla Miłosza poszukiwaną figurą postawy symbolizującej odpowiedzialność człowieka tworzącego historię wobec Natury.

Z perspektywy lat Miłosz pisze w Ziemi Ulro:

Teraz widzę nić, która łączy różne moje fazy, tj. wpływy jakim ulegałem: dogmatyka katolicka, St. Brzozowski, O.W.M., heglizm w osobie mojego przyjaciela Tadeusza Juliusza Krońskiego, Swedenborg, Simone Weil, Szestow, Blake. Tą nicią jest mój antropocentryzm i niechęć do Natury ${ }^{38}$.

Pojęcie antropocentryzmu służy tu Miłoszowi jako formuła uspójniająca występowanie w jego biografii twórczej inspiracji, a w konsekwencji - wątków, tradycyjnie sytuowanych biegunowo: tematyki marksistowskiej i wrażliwości religijnej, postawy „specjalisty od komunizmu” $i$,poety lirycznego”, prawdy historycznej i przekraczającej ją, ale na niej opartej, wartości uniwersalnej.

Antydogmatyzm, przekraczanie i współwystępowanie w diachronicznym porządku - wydawałoby się - sprzecznych inspiracji i stanowisk światopoglądowych słusznie eksponuje też Miłosz w pisarstwie Brzozowskiego:

Zaledwie zaczęto go zaliczać do rozsądnych pozytywistów - pisał o autorze Idei... - przerzucił się na propagandę wyśmiewanej moderny. Zaledwie wyrobił sobie nazwisko jako naczelne pióro krytyczne Młodej Polski, obrócił się przeciwko niej w imię marksizmu i socjalizmu. W tym też mógł osią́ć i jako wolterianin, humanitarysta, materialista zbierać oklaski na lewicy. On natomiast wdał się w dziwaczne rozmyślania nad Heglem i Marksem [...]. I był nietaktowny: przyznawał się do wiary w Boga. (s. 142-143)

Odnotowując przeciwieństwa ideowe stanowiska Brzozowskiego, Miłosz upomina się o odnalezienie „wyższej racji” biegunowo skrajnych postaw krytyka, zdiagnozowanie ich podskórnej spójności.

$3^{8}$ C. Miłosz, Ziemia Ulro, Warszawa 1982, s. 87. 
W istocie małżeństwa między filozofiami, tak charakterystyczne dla Brzozowskiego, nasuwają zbyt wiele refleksji, by zbyć je naganą. Godzenie światopoglądów sprzecznych jest nie więcej niż karygodnym eklektyzmem, tylko jednak wtedy, kiedy rozpatrujemy te światopoglądy w chwili, wyłączając czas, który w nich się wyraża i w nich pracuje. (s. 104)

Brzozowski bowiem - przekonuje Miłosz - „nie wyrzekał się swoich wcześniejszych poglądów [...], w każdym jego ruchu można wyczuć tę samą orientację i ruch następny ją tylko wzmacniał, jakby całe życie wyrabiał sobie tylko środki pojęciowe, posuwając się od niedostatecznych do bardziej zadowalających" (s. 58).

Perspektywa antropocentryzmu zatem, tłumacząca, czy też usprawiedliwiająca współwystępowanie sprzeczności w ideowym przesłaniu Brzozowskiego, jest najsilniej podkreślaną przez Miłosza cechą jego pisarstwa, ale przede wszystkim jest odnajdywanym z nim powinowactwem, eksponowaną przez Miłosza zbieżnością sposobu myślenia autora Idei... z tęsknotą przekraczania biegunów $\mathrm{w}$ dokonywanych przez siebie samego wyborach ideologicznych i estetycznych. To przekraczanie opisać można przede wszystkim jako uwidaczniającą się w jego twórczości dynamikę naprzemiennych skrajności (np. okresowo uprawiana poezja społeczna i późniejszy deklaracyjny i praktyczny sprzeciw wobec niej, tematyka lewicowo-społeczna i wątki metafizyczne), a także utożsamić ze stawianym sobie postulatem odnajdywania sposobu łączenia opozycyjnych wyborów, z potrzebą odnajdywania uzasadnień dla postaw i przekonań alternatywnych wobec skrajności światopoglądowych i poetyckich (wartości uniwersalne / wartości historyczne, czysta sztuka / sztuka konkretna ${ }^{39}$, mistycyzm / idee rewolucyjne ${ }^{40}$ ).

39 Por. np. Miłoszową tematyzację tych opozycji z dyskusji z Gombrowiczem: „Myślę, że śpiew przyszłości może się narodzić tylko pod piórem ściśle związanym z czasem teraźniejszym. Zarzut, jaki mogę sobie postawić, to ten, że moje pióro nie jest dostatecznie teraźniejsze, że nie dotyka całego splotu zagadnień, które są”. „Tak, ma Pan rację mówiąc, że za mało jest we mnie śpiewu przyszłości. Bo nie pokazałem może, jak by należało, że protest wobec zabójczej bistoricité, która wydrąża człowieka od wewnątrz, tak, że zostaje z niego tylko powłoka jak u wyschniętego kraba, że ten protest możliwy jest jedynie w imię pełniejszego historycznego spojrzenia, w imię jej dania wolnego pola nowej czystej walce - tak, aby człowiek spragniony absolutnych wartości, przez historyczność mógł przezwyciężać historyczność” (C. Miłosz, Gombrowiczowi, w: Kontynenty, s. 273, 272).

$4^{\circ}$ Wypowiedź młodego Miłosza: „Lepiej jeśli mistycy katoliccy pozostaną nauczycielami nielicznych rewolucyjnych poetów. Jakiś dziennikarz kpił z połączenia rewolucjonizmu i mistycyzmu. A jeżeli zarówno mistycyzm, jak 
Swoją nierozstrzygalną „przypadłość umysłu artysty ze wszystkimi jego zaletami i wadami” - umysłu, który „postępował od przeczenia do przeczenia, próbując przezwyciężyć sprzeczności właściwie się w nich lubował" "11, a także ich konsekwencje Miłosz niejednokrotnie tematyzował. „Ciągłe przeginanie się zanadto $\mathrm{w}$ jedną czy drugą stronę, ciągłe skoki z pozycji historycznej w «wiecznościową» i odwrotnie, z tęsknotą do takiego ich połączenia, że obie znajdą swój własny wymiar - to był i jest dla mnie najważniejszy powód do zmartwień” - pisał w tekście poświęconym Gombrowiczowi ${ }^{42}$, a w Rodzinnej Europie wyznawał: „Byłem między dwoma biegunami: kontemplacją nieruchomego punktu i nakazem czynnego udziału w historii, transcendencją i stawaniem się. Nie udało mi się tych skrajności pogodzić, a żadnej nie chciałem poświęcić" ${ }^{43}$.

Miłosz $\mathrm{w}$ jednej z dotyczących go antynomii rozgrywał i powtarzał konflikt Brzozowskiego między czynem a słowem (by nawiązać do tytułu książki młodopolskiego adwersarza autora Legendy Młodej Polski...), zatem między dostrzeganymi zobowiązaniami literatury wobec rzeczywistości pozaliterackiej (społecznej i politycznej), świadomością jej pozaartystycznych powinności, a uchwytywaną samoistną wartością sztuki, jej znaczenia uobecnionego $\mathrm{w}$ formie. Ten spór określał swego czasu główny temat polemiki Irzykowskiego z Brzozowskim, ale rozgrywał się też na kartach pism samego Brzozowskiego, owocując „konsekwentną niekonsekwencją" (s. 38), nieustannym przemieszczaniem się aprobaty filozofa-krytyka pomiędzy skrajnie różnymi stanowiskami. Konflikt ten nazywał i przeżywał również sam Miłosz:

Odgadywałem, że myśl i słowo nie powinny ulegać naciskom materii, bo rywalizacji z nią nie potrafią wytrzymać i będą musiały zamienić się w czyn, co oznaczałoby, że przekreślają swoje uprawnienia. $\mathrm{Z}$ drugiej jednak strony istniała we mnie zupełnie usprawiedliwiona obawa przed dematerializacją, rozchwianiem się myśli i słowa.

Wnioski wyciąga Miłosz zbieżne z głównymi i najczęstszymi wyborami Brzozowskiego: „Tylko mocny uchwyt za rzeczy do-

i rewolucjonizm są tylko formami tego samego nasycenia, potrzebą serca, które musi wykraczać poza granice czasu, granice miejsc? [...] Można być dalekim od mistycyzmu, a mistyków cenić i czuć. Trzeba tylko wiedzieć o braterstwie, jakie łączy nieprzekupionych” (C. Miłosz, Przygody młodego umystu, s. 87).

4 C. Miłosz, Rodzinna Europa, s. 123.

$4^{2}$ C. Miłosz, Gombrowiczowi, w: Kontynenty, s. 273.

43 C. Miłosz, Rodzinna Europa, s. 131. 
tykalne, poddane ciągłej zmianie, a więc za tę dźwignię, która je w społeczeństwie porusza, czyli politykę, mógłby od tego uratować" ${ }^{44}$.

Ową łączność duchową Brzozowskiego i Miłosza, opartą właśnie na „podobnych oscylacjach i rozdarciach”, komentował swego czasu Józef Czapski, pisząc:

[...] niejedno Miłosza i Brzozowskiego łączy: te same pasje spoleczne, te same pasje problemów intelektualnych i świadomość ich absolutnej powagi, ta sama rzetelność i wrażliwość na moralny aspekt zagadnień, podobne oscylacje i rozdarcia, których autor ani nie zamazuje, ani nie ukrywa, ale przeciwnie, próbuje doszukać ich sensu ${ }^{45}$.

W perspektywie takich właśnie oscylacji książka Miłosza o Brzozowskim - $\mathrm{z}$ pozoru sprawozdawcza zarówno na płaszczyźnie prezentowanej biografii, jak i zestawień filozoficznych tez Brzozowskiego - okazuje się przy uwzględnieniu osobistego a głęboko ukrytego planu tekstu swego rodzaju książką autobiograficzną, książką, w której Miłosz, pisząc o autorze Idei..., dokonuje subtelnej, ale wyraźnej autokreacji. Przypomnijmy jeszcze raz słowa Miłosza kierowane do Walickiego, odsłaniające głębokie motywacje zajęcia się Brzozowskim: „jakiś rodzaj wiosła był mi potrzebny jako człowiekowi”.

Narzędziem tej autokreacji jest zatem sugestia istnienia podobieństw z młodopolskim krytykiem, jej zakładanym efektem zaprogramowanie takiego „stylu odbioru” własnych wyborów życiowo-literackich, który sytuuje Miłosza na pozycji osobnej, pozycji przypominającej miejsce niedocenionego - a wyjątkowego - florenckiego samotnika.

Sytuacja biograficzna zatem - emigracja, oskarżenie o zdradę, wrogość w kraju i brak poczucia osadzenia na emigracji - to biograficzny punkt wyjścia, funkcjonujący jako swoiste uzasadnienie zarysowywanych subtelnie przez Miłosza paraleli. Dalsze funkcjonują na płaszczyźnie diagnozy źródeł nieporozumień wokół Brzozowskiego. W tym planie książka Miłosza, jak słusznie podkreślała Danuta Ulicka ${ }^{46}$, jest swoistym traktatem moralnym, socjologiczno-etycznym wykładem o psychice narodu polskiego. Wskazując bowiem na źródło wspomnianych nieporozumień wokół Brzozowskiego (a pośrednio także własnego, konfrontowanego $\mathrm{z}$ florenckim samotnikiem, doświadczenia), Miłosz

44 Ibidem, s. 130-131.

45 J. Czapski, O Brzozoweskim, „Kultura” 1963, nr 1-2.

${ }^{46}$ D. Ulicka, op.cit. 
dociera do trwałych, historycznie uzasadnionych stereotypów funkcjonowania polskiej inteligencji, opanowanej intelektualną biernością, rosyjską fobią, dogmatyczną wykładnią każdej myśli czy idei. Taka interpretacja ma w efekcie nie tylko tłumaczyć nieporozumienia wokół Brzozowskiego, ale również - zgodnie z planem hermeneutycznego i antyscjentystycznego aktualizowania analiz wydarzeń i tekstów historycznych - diagnozować Miłoszową współczesność.

Płaszczyznę biograficznych paraleli dopełniają tematyzowane niejednokrotnie wiele lat po napisaniu Człowieka wśród skorpionów..., okresowo zmienne współbieżności własnych wyborów światopoglądowych i intelektualnych z postawą Brzozowskiego: od młodzieńczego radykalizmu i lewicowego fanatyzmu po najgłębszą diagnozowaną wspólnotę metody myślenia niespolegliwego, niekonsekwentnego wobec doktryn filozoficznych i estetycznych, sytuującego się poza ideologicznymi biegunami, głównie na zasadzie ich przekraczania. W tym planie książka Miłosza o Brzozowskim jest właśnie najsilniej zarysowaną propozycją klucza interpretacyjnego własnej twórczości przez kreację wizerunku siebie jako osobnego intelektualisty, powtarzającego do pewnego stopnia nie tylko los, ale przede wszystkim uwolniony od uproszczeń i dogmatycznych wykładni myśli sposób pisania wybitnego krytyka.

Miłosza książka o Brzozowskim jest jednak także zasadniczą pozycją niezbędną dla „czytania” twórczości samego Brzozowskiego, przede wszystkim z perspektywy uchwycenia początków jego ponownego odkrycia. W przedmowie do nowego wydania Człowieka wśŕód skorpionów... w latach 90. Miłosz pisze, że książka ta należy do „wieku ideologii”, który się skończył, zatem i Brzozowski musi trafić do lamusa ${ }^{47}$. Zainteresowanie „zbawionym heretykiem” - by posłużyć się tytułem przedmowy Sławomira Sierakowskiego do niedawno wznowionego wydania Ptomieni ${ }^{48}$ - tego nie zapowiada, i to zarówno ze względu na wieloaspektowość i gęstość treści dzieła Brzozowskiego, jak i właśnie na ową szaloną metodę sytuowania się poza biegunami, poza opozycjami myśli, która określa tożsamość wyobraźni nowoczesnej. W owym procesie „wybawiania heretyka” przez rehabilitację - zarówno jego biografii, jak i twórczej „konsekwentnej niekonsekwencji” - książka Miłosza z roku 1962 jest pierwsza.

47 C. Miłosz, Przypispo latach..., s. 9.

$4^{8}$ Por. S. Sierakowski, Powrót zbawionego beretyka, w: S. Brzozowski, Ptomienie, Warszawa 2007. 


\section{SYLWIA PANEK}

\section{Miłosz's Response to Brzozowski. On Człowiek wśród} skorpionów... [Man among'Scorpions...] and More

The aim of the author of the article is to investigate Miłosz's relation to Stanisław Brzozowski. Proceeding from the interpretation of Miłosz's Człowiek wśród skorpionów..., and diagnosing his personal motivation for turning to Brzozowski's works in 1963, the author investigates the avenues of dialogue between Miłosz and Brzozowski, and their unsystematically expresses common points. The article, thus, presents various stages of influence of Brzozowski's work and ideas on Miłosz: from the 1930s, when Miłosz was inspired by Brzozowski's left-wing fanaticism, through the common opposition against anti-intellectualism and the Polish identity understood as a set of Romantic symbols and gestures, up to the fascination with Russian culture and Marxism. The deepest affinity of both authors seems to be the attitude of anthropocentrism, identified and exposed by Miłosz himself, and understood as hostility towards nature and belief in nature's determinism, but also as a formula that gives coherence to the philosophical themes, found in both authors' work, which are thought to be polarised and incompatible. In the conclusion, the author of the article states that positioning himself with reference to Brzozowski was, for Miłosz, a tool of selfcreation, an attempt to control the reception and interpretation of his own work, and to place Miłosz in a separate and exceptional position, akin to the position of Brzozowski, the extraordinary and unrecognized philosopher and critic of Polish early modernism.

Keywords: Czesław Miłosz, Stanisław Brzozowski, Miłosz’s self-creation, Marxism, Russia in Miłosz's works.

Sylwia Panek - doktor, adiunkt w Zakładzie Antropologii Instytutu Filologii Polskiej UAM, absolwentka filozofii i filologii polskiej UAM, autorka książki Krytyk w przestrzeniach literatury i filozofii. O młodopolskich wypowiedziach polemicznych Karola Irzykoweskiego (2004), redaktorka serii wydawniczej „Polemika krytycznoliteracka w Polsce”. Obszary zainteresowań: historia i teoria krytyki literackiej XIX i XX w., pogranicza filozofii oraz literaturoznawstwa. 